\title{
Intervention of gender friendly land preparation technologies for drudgery reduction of hill farm women
}

\author{
Jatinder Kishtwaria $^{\mathrm{a}}$ and Aruna Rana ${ }^{\mathrm{b}}$ \\ a Department of Family Resource Management, College of Home Science, CSK Himachal Pradesh Agricultural \\ University, Himachal Pradesh, India 176062 \\ ${ }^{\mathbf{b}}$ Department of Family Resource Management, College of Home Science, CSK Himachal Pradesh Agricultural \\ University, Himachal Pradesh, India 176062
}

\begin{abstract}
Inventory of all agricultural tasks depicted land preparation by women farmers as one of the most drudgery prone task with high energy cost, thereby, making it amenable to ergonomic interventions in terms of improved technologies (clod breaker, improved plough/'danella') to relieve women from high energy demands, time spent and associated drudgery. The study was conducted in two hill states of India viz. Himachal Pradesh (35 villages and 900 representative samples) and Uttrakhand (10 villages and 900 representative samples). Experimental data were conducted on representative sub sample of 60 hill farm women of both the states to assess physiological workload and musculo-skeletal problems both while working with traditional tools along with improved tools by employing selected parameters viz. physical fitness level, physiological parameters etc. The results showed that heart rate values were more than acceptable limits for task performed with the traditional tools as compared with improved tools. Significant reduction in the heart rate was observed while working with improved tools. Analysis of MSDs showed that the postural stress and severity of pain in various body parts was reduced by adopting new technology. Hence, the use of improved land preparation tools is recommended over the existing ones for drudgery reduction.
\end{abstract}

Keywords: gender, agriculture, musculoskeletal disorders

Email: jkishtwaria@rediffmail.com

Tel.: +91 1894 230407, Mobile: +91 9418478407, Fax: +91 1894230511 


\section{Introduction}

Rural women form the most important productive work force in the economy of majority of the developing nations including India. Spread over, 640,000 villages, India represent about 10 percent (225 million) of total world workforce in agriculture [14]. Amongst rural women workers, 81 per cent are employed in agriculture as labourers and cultivators. Number of women as agriculture labourers (873) is more than the cultivators (478) [17].

Himachal Pradesh and Uttrakhand are small hill states of India in north western Himalaya, where agriculture is the mainstay of population due to low level of Industrialization. It is due to small landholdings and men's migration for more lucrative jobs leaving all responsibilities including agriculture on women [9] Thus, rural India is witnessing a process which could be described as Feminization of Agriculture. Consequently women are increasing their workload and taking care of a wider scope of agriculture tasks, but the degree to which they have access to improved technologies need special consideration [17].

Most of the work performed by women farmers is carried out by age old and any available tools which are not women friendly causing fatigue, drudgery and ill health. It is reported that men have adopted mechanized agriculture and women's work has remained predominantly manual. The root cause of women's suffering is ignorance, age old methods of doing the work, inappropriateness of the technology, attitudinal constraints such as innate conservation and resistance to change [7].

The technological empowerment of farm women with occupational safety and work output is the need of the day [21]. The technologies should fulfill the criterion of reduced workload, time spent, energy expended, stress, strains, body pains, fatigue and drudgery and in turn enhance efficiency, productivity, quality of produce, income and satisfaction of the farm women.

Inventory of all agricultural tasks depicted land preparation by women farmers as one of the most drudgery prone task with high energy costs, thereby, making it amenable to ergonomic intervention [8].

Characteristic of manually handling materials in tasks such as land preparation involved a variety of traditional postures like sitting, squatting, stooping, sitting cum bending, etc. There are various ill effects of such postures [23, 20, 3].

Therefore, it is imperative to provide the farm women with ergonomically sound women friendly improved technology so as to enhance their efficiency and productivity as well as reduce pains and drudgery.

Thus, the study was undertaken with the following specific objectives:

1. To identify the drudgery index of farm women in various agricultural operations

2. To ascertain the health status of hill farm women

3. To assess the ergonomic cost of land preparation work with existing and improved technology.

\section{Methodology}

The study was conducted in two hill states of India viz. Himachal Pradesh and Uttrakhand in the following phases:

Phase I - Drudgery Index of farm women involved in various agricultural tasks

Phase II - Health status of hill farm women

Phase III - Ergonomic cost of land preparation operations with existing and improved technology. 
Phase I- Drudgery of farm women involved in various agricultural tasks

A survey was conducted in two hill states of India viz. Himachal Pradesh (35 villages and 900 representative sample) and Uttrakhand (10 villages and 500 representative sample) and data were collected on a well-structured, pre-tested interview schedule. The data were analyzed to identify the drudgery prone tasks in agriculture on hierarchy basis by consolidating the different parameters viz. (i) time expended on each task, (ii) frequency of activity performed and (iii) degree of difficulty experienced while doing the land preparation operations by linear combination method. The coefficients of each activity were drawn on above three parameters to calculate the drudgery Index as follows.

$$
\text { Drudgery Index }=\frac{\mathrm{X}+\mathrm{Y}+\mathrm{Z}}{3} \times 100
$$

Phase II - Health status of hill farm women

Health status of farm women involved in drudgery prone activities was ascertained using the following variables, tools, techniques and formulae.

\begin{tabular}{|l|l|l|}
\hline Variables & Tools/Techniques & Formula \\
\hline Body weight $(\mathrm{Kgs})$ & Weighing balance & - \\
\hline Body height $(\mathrm{Cms})$ & Height measuring rod & - \\
\hline $\begin{array}{l}\text { Body Mass Index } \\
\text { (BMI) }\end{array}$ & - & $\begin{array}{l}\text { Weight }(\mathrm{kgs}) / \text { Heig } \\
\mathrm{ht}^{2}(\mathrm{~cm})\end{array}$ \\
\hline $\begin{array}{l}\text { Physical Fitness Index } \\
\text { (PFI) }\end{array}$ & $\begin{array}{l}\text { Step Stool } \\
\text { Ergomaster }\end{array}$ & \\
\hline $\begin{array}{l}\text { Lean Body mass } \\
\text { (LBM) }\end{array}$ & Skin fold calipers & - \\
\hline Oxygen consumption & $\left(\mathrm{VO}_{2}\right.$ Max $)$ & \\
\hline
\end{tabular}

Interventions through modified improved technologies

The existing tools were improved as per anthropometric data and physical fitness levels of hill farm women on ergonomic parameters. Two tools for land preparation were improved and introduced after modification viz. clod breaker and hand plough 'danella'. These tools were made light in weight to ease the operation with suitable length as per women's dimensions and convenient handles.

Phase III Ergonomic cost of land preparation with existing and improved technology.

Sixty healthy, non-pregnant, hill farm women without major illness were selected for experiments to assess the ergonomic cost of land preparation operations with existing and improved technology

\begin{tabular}{|c|c|c|}
\hline Parameters & Tools/Techniques & Formula \\
\hline \multicolumn{3}{|c|}{ i) Physiological parameters } \\
\hline a) Heart Rate & $\begin{array}{l}\text { Polar Heart Rate } \\
\text { Monitor (NV } \\
\text { Vantage mode) }\end{array}$ & - \\
\hline b) Energy Expenditure & - & $\begin{array}{l}0.159 * \text { average } \\
\text { heart rate- } 8.72\end{array}$ \\
\hline $\begin{array}{l}\text { c) Total Cardiac Cost of } \\
\text { Work (TCCW) }\end{array}$ & - & $\begin{array}{l}\text { Cardiac Cost of } \\
\text { Work }+ \text { Cardiac } \\
\text { Cost of Recovery }\end{array}$ \\
\hline 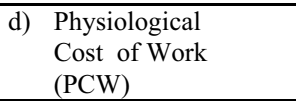 & - & $\begin{array}{l}\text { TCCW/total time } \\
\text { of work }\end{array}$ \\
\hline \multicolumn{3}{|c|}{ ii) Psycho - Physiological parameters } \\
\hline $\begin{array}{l}\text { e) Rate of Perceived } \\
\text { Exertion }\end{array}$ & Borg's Scale & - \\
\hline \multicolumn{3}{|l|}{$\begin{array}{l}\text { iii) Bio- mechanical } \\
\text { parameters }\end{array}$} \\
\hline $\begin{array}{l}\text { a)Musculo Skeletal } \\
\text { problems }\end{array}$ & Human Body Map & - \\
\hline b) Postural analysis & Flexi curve & - \\
\hline c) Muscular strength & Grip dynamometer & $\begin{array}{l}\text { Strength of } \\
\text { muscles at rest- } \\
\text { strength of } \\
\text { muscles at } \\
\text { work/strength of } \\
\text { muscles at rest* } \\
100\end{array}$ \\
\hline \multicolumn{3}{|c|}{ iv) Environmental conditions } \\
\hline a) $\quad$ Temperature & Thermometer & - \\
\hline b) Relative humidity & Hygrometer & - \\
\hline v) Output parameters & \multicolumn{2}{|c|}{ Measuring tape / Weighing balance } \\
\hline
\end{tabular}
on following parameters

Statistical Analysis

Paired t-test was employed to find out the significant difference if any between existing practices and after adoption of improved technologies by women in land preparation operations 


\section{Results}

Table 1

Physical characteristics and health status of the respondents

\begin{tabular}{|l|l|l|}
\hline $\begin{array}{l}\text { Physical } \\
\text { Characteristics }\end{array}$ & $\begin{array}{l}\text { Himachal } \\
\text { Pradesh }\end{array}$ & Uttrakhand \\
\cline { 2 - 3 } & Mean \\
\hline Age (yrs) & 35.8 & 36 \\
\hline Height $(\mathrm{cm})$ & 152.4 & 154 \\
\hline Weight $(\mathrm{kg})$ & 53.01 & 47.5 \\
\hline LBM $(\mathrm{kg})$ & 27.85 & 24.4 \\
\hline $\mathrm{BMI}$ & 22.85 & 20.17 \\
\hline $\mathrm{V} 0_{2}$ Max & 25.35 & 32.08 \\
\hline
\end{tabular}

Health status of farm women of the two hill states was ascertained in terms of LBM, BMI and Vo2 max. The average age of women of Himachal Pradesh was 35.8 years having an average height of $152.4 \mathrm{~cm}$,

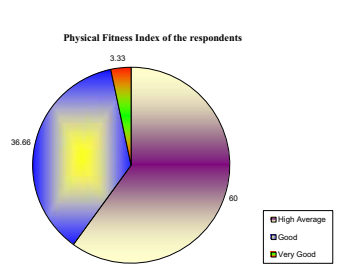
weight $48.73 \mathrm{~kg}$ with a BMI of 22.85 whereas, women of Uttrakhand were in the average age group of 36 years with a height of

$154 \mathrm{~cm}$ and $47.5 \mathrm{~kg}$ of body weight. Physical fitness level of majority of respondents was found to be high average followed by good (Table 1) in both the states.

Table 2

Drudgery Index of various agricultural operations undertaken by hill farm women

\begin{tabular}{|l|c|c|}
\hline \multirow{2}{*}{ Activities } & $\begin{array}{c}\text { Himachal } \\
\text { Pradesh }\end{array}$ & Uttrakhand \\
\cline { 2 - 3 } & \multicolumn{2}{|c|}{ Drudgery Index } \\
\hline $\begin{array}{l}\text { Removing of stalks } \\
\text { and stubble }\end{array}$ & 31 & - \\
\hline Clod breaking & - & 45 \\
\hline Harrowing & 28.3 & 33.3 \\
\hline Heaping & 27.3 & 32.76 \\
\hline Bagging/matting & 23.6 & 28.26 \\
\hline
\end{tabular}

After drawing coefficients of difficulty score, performance score and time score by linear combination method, the drudgery index calculated was maximum for removing stalks and stubble, clod breaking followed by harrowing and heaping, bagging and matting amongst various agricultural tasks carried out by hill farm women (Table 2).

Table 3a

Ergonomic cost of work of women while performing the land preparation operations using existing and improved tools

1 - Dinkyana / clod breaker

2 - Traditional 'Danella' and Improved plough 'danella'

\begin{tabular}{|c|c|c|c|c|c|c|c|c|c|}
\hline \multirow[t]{3}{*}{$\begin{array}{l}\text { Paramete } \\
\text { rs }\end{array}$} & \multicolumn{2}{|c|}{$\begin{array}{c}\text { Himachal } \\
\text { Pradesh }\end{array}$} & \multicolumn{4}{|c|}{ Uttrakhand } & \multicolumn{3}{|c|}{ Significant change } \\
\hline & \multirow{2}{*}{$\begin{array}{l}\text { Traditio } \\
\text { nal } \\
\text { Clod } \\
\text { breaker }\end{array}$} & \multirow{2}{*}{$\begin{array}{l}\text { Improv } \\
\text { ed Clod } \\
\text { breaker }\end{array}$} & \multicolumn{2}{|c|}{ d Traditional } & \multicolumn{2}{|c|}{ Improved } & \multirow[t]{2}{*}{$\begin{array}{c}\text { Himach } \\
\text { al } \\
\text { Pradesh }\end{array}$} & \multicolumn{2}{|c|}{ Uttrakhand } \\
\hline & & & 1 & 2 & 1 & 2 & & 1 & 2 \\
\hline \multicolumn{10}{|c|}{\begin{tabular}{|l|} 
Physiological and Psycho-physiological parameters \\
\end{tabular}} \\
\hline $\begin{array}{l}\text { Average } \\
\text { working } \\
\text { heart rate } \\
\text { (b/min) }\end{array}$ & 117 & 107 & 124.5 & 120.3 & 99.2 & 93.5 & $2.57^{*}$ & $1.92 *$ & $1.82^{*}$ \\
\hline $\begin{array}{l}\text { Average } \\
\text { energy } \\
\text { expenditur } \\
\text { e } \\
(\mathrm{kj} / \mathrm{min})\end{array}$ & 9.88 & 8.29 & $\begin{array}{c}11.0 \\
7\end{array}$ & $\begin{array}{c}10.4 \\
0\end{array}$ & 7.06 & 6.14 & - & - & - \\
\hline $\begin{array}{l}\text { Average } \\
\text { TCCW(be } \\
\text { ats) }\end{array}$ & 1055 & 616.30 & 505 & 515 & 183 & 175 & $6.86^{*}$ & 0.75 & 1.06 \\
\hline $\begin{array}{l}\text { Average } \\
\mathrm{PCW}(\mathrm{b} / \mathrm{mi} \\
\text { n) }\end{array}$ & 35.16 & 20.54 & 50.5 & 51.5 & 18.3 & 17.5 & - & - & - \\
\hline \begin{tabular}{|l|} 
Average \\
RPE
\end{tabular} & 4 & 3 & 4 & 3 & 4 & 3 & $2.68^{*}$ & $4.01^{*}$ & $2.66^{*}$ \\
\hline
\end{tabular}

The findings of ergonomic assessment for the traditional /improved tools under the study showed that heart rate values were more than acceptable limits while land preparation with the traditional tool (117 bpm and $99.2 \mathrm{bpm}$ - clod breaking and 124.5 bpm - 'danella'). The comparative assessment between use of traditional vs. improved tools in both the states showed better results in terms of heart rate (Improved clod breaker - 107 and $93.5 \mathrm{bpm}$, 'Danella' - 120.3 bpm) (Table 3a). Similar trend was observed in the total cardiac cost of work and the physiological cost of work. Significant changes in the heart rate $(2.57 *$ and $1.92 *$ - clod breaker, $1.82 *$ improved plough 'danella'), TCCW (6.86* - clod breaker) and RPE (2.68* and 4.01* - clod breaker, 2.66*- improved plough 'danella') were observed 
while carrying out the land preparation activity with the improved tools.

Table 3b

Assessment of bio-mechanical stresses of women while performing the land preparations operations using existing and improved tools

\begin{tabular}{|c|c|c|c|c|c|c|}
\hline \multirow[t]{3}{*}{ Parameters } & \multicolumn{2}{|c|}{$\begin{array}{c}\text { Himachal } \\
\text { Pradesh }\end{array}$} & \multicolumn{4}{|c|}{ Uttrakhand } \\
\hline & \multicolumn{2}{|c|}{ Traditio Clod } & \multicolumn{2}{|c|}{ Traditional } & \multicolumn{2}{|c|}{ Improved } \\
\hline & nal & breaker & dinkyana & danella & $\begin{array}{l}\text { Clod } \\
\text { breaker }\end{array}$ & $\begin{array}{l}\text { Improved } \\
\text { plough } \\
\text { danella }\end{array}$ \\
\hline \multicolumn{7}{|c|}{ Grip strength } \\
\hline Right & 10.8 & 8 & -11.11 & - & - & - \\
\hline Left & 9.63 & 7 & 11.11 & -14.28 & - & - \\
\hline $\begin{array}{l}\text { Angle of } \\
\text { normal } \\
\text { curve }\left({ }^{\circ}\right)\end{array}$ & - & - & 195 & 195 & 187 & 187 \\
\hline $\begin{array}{l}\text { Angle of } \\
\text { bend }\left({ }^{\circ}\right)\end{array}$ & - & - & 184 & 186 & 200 & 195 \\
\hline $\begin{array}{l}\text { Angle of } \\
\text { deviation }\left({ }^{\circ}\right)\end{array}$ & - & - & 19 & 10 & 11 & 5 \\
\hline
\end{tabular}

The hand muscles were less fatigued with the use of improved tools (Table 3b). The new improved tools for land preparation were able to lessen the angle of deviation, improve posture and lessen fatigue.

Table 3c

Musculo Skeletal problems of women while workingwith the traditional and improved tools under land preparation

\begin{tabular}{|l|l|l|l|}
\hline Activities & Tools Used & \multicolumn{1}{|c|}{$\begin{array}{c}\text { Himachal } \\
\text { Pradesh }\end{array}$} & \multicolumn{1}{|c|}{ Uttrakhand } \\
\cline { 3 - 4 } & & \multicolumn{2}{|c|}{ Musculo Skeletal Problems } \\
\hline $\begin{array}{l}\text { Land } \\
\text { preparation }\end{array}$ & $\begin{array}{l}\text { Traditional } \\
\text { Tool/Method }\end{array}$ & $\begin{array}{l}\text { Very severe } \\
\text { pain in } \\
\text { shoulders, } \\
\text { upper arm } \\
\text { and hands }\end{array}$ & $\begin{array}{l}\text { Very severe pain } \\
\text { in upper arm and } \\
\text { severe pain in } \\
\text { low back }\end{array}$ \\
\cline { 2 - 4 } & Clod breaker & $\begin{array}{l}\text { Mild pain in } \\
\text { shoulders }\end{array}$ & $\begin{array}{l}\text { Mild pain in low } \\
\text { back }\end{array}$ \\
\cline { 2 - 4 } & $\begin{array}{l}\text { Traditional } \\
\text { Tool/Method }\end{array}$ & - & $\begin{array}{l}\text { Very Severe pain } \\
\text { in low back } \\
\text { shoulders, thighs } \\
\text { and lower legs }\end{array}$ \\
\cline { 2 - 4 } & $\begin{array}{l}\text { Improved } \\
\text { hand plough } \\
\text { Danella' }\end{array}$ & - & $\begin{array}{l}\text { Moderate pain in } \\
\text { shoulder and } \\
\text { wrists and hands }\end{array}$ \\
\hline
\end{tabular}

The use of traditional tools by the farm women led to the development of various musculo - skeletal problems like severe pain in upper arm, hands, shoulders and lower legs. The pain still persisted while working with the improved tools that is danella and clod breaker but the severity was reduced to a considerable level. (Table 3c)

Table 3d

Production output and environmental parameters while land preparation by existing and improved tools

\begin{tabular}{|c|c|c|c|c|c|c|c|c|}
\hline \multirow[t]{3}{*}{ Parameters } & \multicolumn{2}{|c|}{$\begin{array}{l}\text { Himachal } \\
\text { Pradesh }\end{array}$} & \multicolumn{4}{|c|}{ Uttrakhand } & \multicolumn{2}{|c|}{$\begin{array}{l}\text { Significant } \\
\text { change }\end{array}$} \\
\hline & \multirow{2}{*}{$\begin{array}{l}\text { Tradit } \\
\text { ional }\end{array}$} & \multirow{2}{*}{$\begin{array}{l}\text { Impro } \\
\text { ved }\end{array}$} & \multicolumn{2}{|c|}{ Traditional } & \multicolumn{2}{|c|}{ Improved } & \multirow{2}{*}{\begin{tabular}{|c|} 
Himac \\
hal \\
Prad \\
esh \\
\end{tabular}} & \multirow{2}{*}{$\begin{array}{c}\text { Uttrakh } \\
\text { and }\end{array}$} \\
\hline & & & 1 & 2 & 1 & 2 & & \\
\hline \multicolumn{9}{|c|}{ Output parameters } \\
\hline $\begin{array}{l}\text { Coverage } \\
\text { of land } \\
\text { under } \\
\text { operation } \\
\text { (sq. mt.) }\end{array}$ & 137.62 & 140.05 & 208 & 302.45 & 202.8 & 219.7 & 0.20 & \begin{tabular}{|c} 
Clod \\
preaker- \\
$14.30^{*}$ \\
mproved \\
plough - \\
$4.64 *$
\end{tabular} \\
\hline \multicolumn{9}{|c|}{ Environmental parameters } \\
\hline $\begin{array}{l}\text { Mean } \\
\text { Ambient } \\
\text { temperatu } \\
\text { re }\left({ }^{C}\right)\end{array}$ & 30.28 & $\begin{array}{l}27.2 \\
8\end{array}$ & $\begin{array}{l}28.3 \\
5\end{array}$ & 27.80 & $\begin{array}{l}20.1 \\
6\end{array}$ & $\begin{array}{l}19.2 \\
7\end{array}$ & \multirow{2}{*}{\multicolumn{2}{|c|}{$\begin{array}{l}\text { Comfortable } \\
\text { temperature } \\
\text { within } \\
\text { acceptable } \\
\text { limits }\end{array}$}} \\
\hline $\begin{array}{l}\text { Mean } \\
\text { Relative } \\
\text { Humidity } \\
(\%) \\
\end{array}$ & 60.17 & $\begin{array}{l}49.4 \\
0\end{array}$ & $\begin{array}{l}50.0 \\
6\end{array}$ & 65.12 & $\begin{array}{l}65.1 \\
9\end{array}$ & & & \\
\hline
\end{tabular}

The experiments were conducted for 30 minutes while working with both traditional and improved tools each to elicit differences if any in production output in both the states. The results depicted that the coverage of land under operation in case of improved treatments was more as compared to the existing condition in both the states i.e. Himachal Pradesh (Existing - 137.62 sq.mt; Improved - 140.05 sq.mt.) and Uttrakhand (Existing -208 sq.mt and 202.8 sq.mt; Clod breaker -302.45 sq.mt. and Improved plough 'Danella' - 219.7 sq.mt.). Significant increase in the coverage of land under operation (clod breaker - 14.30*, Improved plough $-4.64^{*}$ ) was observed which in turn enhanced 
the work efficiency of women involved in land preparation activity.

\section{Discussions}

Hill farm women of India spend long hours (14 to 18) in traditional farming operational with much labour in diversified production system resulting in fatigue, drudgery and ill health [18]. There are certain agricultural operations in which female agricultural workers are considered better than male workers $[2,17]$.

Land preparation involves clod breaking, harrowing and leveling the fields etc in which hill farm women play a key role with high drudgery index for the task in both the States [19] Table 2.

In both the hill states, the physical fitness level of majority of farm women was high average depicted through PFI, BMI and Vo 2 max results (Table1). The vo2 max value of India workers is $2.01 / \mathrm{min}$ and of women 70 to $75 \%$ of man that is $1.51 / \mathrm{min}$.

It is particularly relevant in traditional farming and its related drudgery, slow pace of work, primitive tools and methods where ergonomics might bring solutions by contributing to the work efficiency, productivity and reduced drudgery e.g. new improved clod breaker and hand plough/ 'Danella'. From physiological point of view, the workload refers to demand placed on the cardio respiratory systems and is determined from heart rate values $[16,22]$ cardiac cost of work [4] and human energy cost.

Traditional versus improved tools showed better results in terms of reduced workload stresses on all selected parameters. There are numerous types of work related MSDs that are reported in agriculture [18] and involves risk factors associated with MSDs [13].

Land preparation tasks resulting into severe to very severe pains (Table $3 \mathrm{~b}$ ) conventional tools and equipments are no longer adequate to meet the needs of rain fed agriculture MSD problems were found very high due to faulty design and dimensions of traditional tools.

Designing of tools, equipments and work processes with due consideration of ergonomical characteristics of women are accommodating to prevent MSDs [18] and other associated safety and health issues

Ergo- design alternatives might be perceptive in terms of health, comfort [15] (Table 3 b 3c) can be integrated and tailored in the line of ILO proposed occupational safety and health (OSH) management system [18].

Analysis of MSDs problem and postural stresses on selected parameters showed that severity of pains in various body parts was reduced by adopting new technologies. Output and area covered was more with the use of ergonomically improved tools than the traditional ones thereby significantly increasing the input output ratio [19].

\section{Conclusion}

- Dominant role of rural hill women in agriculture is increasingly understood and recognized

- More women oriented research in agriculture with particular reference to ergonomic design of women friendly tools is emphasized as women have different ergonomic characteristics than men

- Comparative assessment of traditional and improved tools for land preparation depicted significant better results on all ergonomic parameters thereby contributing in reduced drudgery, fatigue, MSDs, body pains ill health and improved output and satisfaction of farm women

\section{References}

[1] AICRP.1999. Ergonomics in Agricultural Activities of Women Farmers. Annual Report, Department of Family Management, GBPUAT, Pantnagar, India

[2] Bhople,R.R. and Pathai. A. 1998. Socio-economic Dimensions of Farm Labour, Rural India, p- 192

[3] Chauhan, M. 1999. Workload and Health Problems in some Occupational Activities. Advanced Training in Ergonomics SNDT Women's University, Mumbai India Feb 22-27. 1999

[4] Chauhan,K. and Sharma, S. 2001. Physiological Cost of Activities performed by women Involved in Construction 
Work. Department of Family Resource Management,GBPUAT, Pantnagar, India

[5] Gite L.P. and Singh G. Ergonomics in agriculture and allied activities in India, Technical Bulletin, CIAE Bhopal 1997.

[6] Gopikuttan G, Kurup KNP. Paddy land conversion in Kerala: An inquiry into ecological and economic aspects in a midlandwatershed region. Kerala research Programme on local level development, centre for development studies, 2004.

[7] Gupta P, Singhal A, Singh S, Sharma P and Jain S. Drudgery faced by farm women in agriculture. National Seminar on Dynamics of Women in Agriculture for National Development (2002) M.P. University of Agriculture and technology, Udaipur, India.

[8] Gandhi, S. Ergonomic Interventions for women in Agriculture Pp 382-389 Ergonomics for everyone Ray Trading Corporation Calcutta 2010.

[9] Kishtwaria, J. and Rana, A., Drudgery of hill farm women due to weeding activity- some solutions, Women at work, Vol. II, Allied Publishers Ltd. (2007), pp. 43-49.

[10] Murphy, D., Safety and health for production agriculture, St. Joseph, MO ASAE, 1992

[11] Meyers, J., Miles, J., Faucett, J., Janowitz, I., Tejeda, D., Weber, E., Smith, R. and Garcia, L., Ergonomics risk factors for musculo skeletal disorder in wine grape vineyard work. Paper presented at National Institute for farm safety, Winnepeg, Canada, 1998.

[12] Mayande, V. Katyal, M. and Sriram, C. 1996 Farm power Deficit; A major factor inhibiting dryland productivity. In proceeding of International Agricultural Engineering Conference. 1:9-31.

[13] National Institute for Occupational Safety and Health 2001. Simple Solutions: Ergonomics for Farm Workers. Report No. 2001-111, 1-53, Washington, D.C. National Academy Press
[14] Nag, P.K. and Nag, A. Drudgery, Accidents and injurious in Indian Agriculture, Industrial Health (2004), 42.149-162

[15] PK Nag and Chatterjee SK, Physiological reactions of female workers in Indian agricultural work. Human factors (1980) 23,607-614.

[16] Rao,S., Physiological costs and perceived exertion for home and farm activities done by rural women. Ph.D. Dissertation, SNDT Women's University Mumbai, 1987.

[17] Suman Agarwal, Gender involvement in Farm Mechanization Issues for Extension and Research. NRC for Women in Agriculture, Bhubneshwar, India.Gite Vol.II, (2007) p 51.

[18] Surbhi Singh and Renu Arora, Ergonomic intervention for preventing musulo skeletal disorders among farm women, J.Agri. Sci. 1(2), 2010, pp. 61-71.

[19] Shalini and Sharma, P. 2000. Ergonomics Evaluation of Workload to determine Work Rest Allowance in Critical Activities for Physical Fitness of Woman Farmers. GBPUAT, Pantnagar, India

[20] Singh,S and Sharma, S. 2000. Ergonomic Assessment of Modes of Carrying Loads and its related Health Hazards in Women Farmers of Kumaon Hills. Department of Family Resource Management, GBPUAT, Pantnagar, India.

[21] Tewari R. Participation of women in fisheries, Ph.D. Thesis, SNDT Women's University, Mumbai, India. 1994

[22] Thakur, T.C. and Sharma, P. 1999. Ergonomics Assessment of Various Activities Performed by women Farmers in Household of Hill Region of U.P. Report: Adhoc Research Scheme, ICAR. Pantnagar, India. 